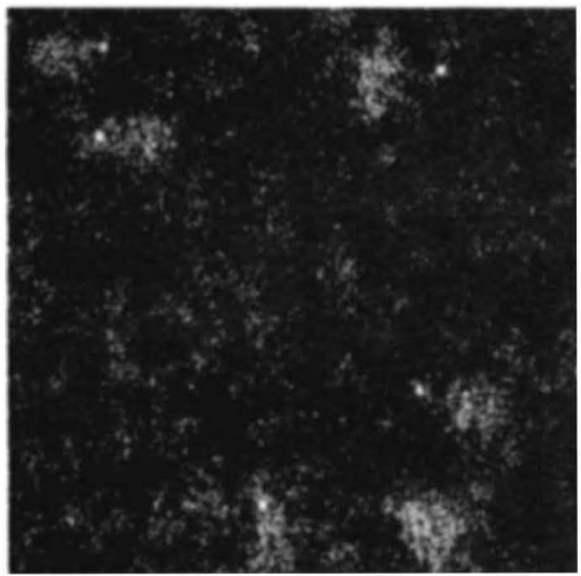

Fig. 3 STEM micrograph of monoclonal Fab' fragments bound to undecagold clusters. The Fab' fragments are $5 \times 3 \times 2 \mathrm{~nm}$ in size; the gold clusters are visible as bright spots on one end of the Fab' fragments.

those few from which $F\left(a b^{\prime}\right)_{2}$ fragments cannot be readily prepared. It is possible to attach more gold clusters to antibodies containing more than one sulfhydryl group in the hinge region.

The future of this new antibody probe may not be limited to electron microscopy. Its unique properties of multiple atom labelling, small size, chemical stability and well-defined attachment location may suggest some interesting medical applications. Other clusters, such as tungstate, are being examined for conjugation in a similar fashion. ${ }^{15}$ Probes with larger clusters which are visible in conventional electron microscopes will widen the use of the technique, while the creation of smaller clusters and fragments will increase the resolution of immunolabels. The application of this new class of cluster immunoconjugates has just begun

James F. Hainfeld is at the Brookhaven National Laboratory, Biology Department, Upton, New York 11973, USA. For more information, fill in reader service number 100.

1. Faulk, W.P. \& Taylor, G.M. Immunochemistry 8, 10811083 (1971)

Singer, S.J. Nature 183, 1523-1524 (1959).

3. Hainfeld J.F. Science 236, 450-453(1987)

4. McPartlin. M.. Mason. R. \& Malatesta, L. J. chem. So McPartlin. M.. Mason.
chem. C, 334, (1969).

5. Bartlett. P.A.. Bauer. B. \& Singer. S.J. Annls Am. chem. Soc. 100 5085-50189(1978).

6. Wall, J.S., Hainfeld, J.F., Bartiett, P.A. \& Singer, S. J. Ultramicrosc. 8, 397-4122 (1982)

7. Safer. D.. Hainfeld, J.F. Wall, J.S. \& Riordan. J. Science 218. 290-29! (1982).

8. Safer, D.. Bolinger, L. \& Leigh, J.S. J. inorg. Biochem. 26. 77-91 (1986)

9. Reardon. J.E. \& Frey. P.A. Biochemistry 23. 3849-3856 (1984)

10. Hainfeld, J.F. \& Wall, J.S. in Recent Advances in Electrot and Light Optical Imaging in Biology and Medicine Vol. 483 (ed. A.P. Somlyo) 181-187 (New York Academy of Sciences, New York, 1986). Sciences. New York. 1986)

11. Safer, D., Hainfeld. J.. \& Wall. 3.S. Biophys. J. 47. 128a (1985).

12. Mosesson. M.W. et al. in Fibrinogen and Its Derisatives (eds Multer-Berghaus. G. et al.). 3-15 (Elsevier. Amsterdam. 1986).

13. Lipka, J.J.. Hainfeld. J.F. \& Wall. J.S. J. Ultrastruct. Re's. 84. $120-129(1983)$

14. Parham, P. J. Immunol. 131, 2895-2902 (1983)

15. Foley. C.J.. Maetia, L.E.. Hainfeld. J.F. \& Wall. J.S. in Proc. 45th Ann. Electron Microsc. Soc. Amer. (ed. Bailey, G.W.) 760-761. (San Francisco Press, 1987)

\section{Labelling techniques}

\author{
The frontiers of molecular biology and immunology have been \\ expanded through the use of radioisotopic and fluorescent labels. \\ Several new reagents are described below.
}

BOEHRINGER Mannheim Biochemicals has recently announced the launch of its nonradioactive DNA labelling and detection kit (Reader Service No. 101). The kit can be used routinely to detect $0.1 \mathrm{pg}$ of DNA in less than 16 hours without significant background, says the company - a degree of sensitivity which should allow the detection of single-copy genes in $1 \mu \mathrm{g}$ of genomic mammalian DNA. The system can be used in dot-, slot- or Southern blots, colony and plaque hybridizations, and in situ hybridizations. The kit includes all components necessary for the labelling of DNA by random primed incorporation of digoxigenin-dUTP, and the detection

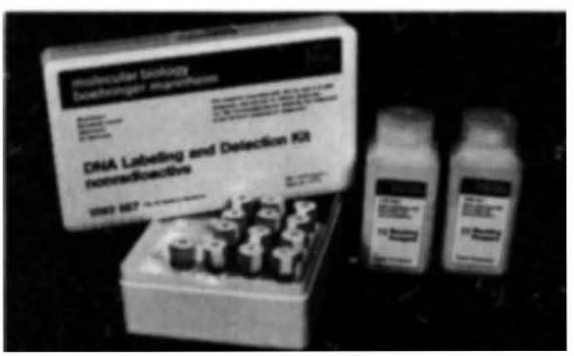

catalogue include monoclonal antibodies to cytomegalovirus, Ki-1 (Reed-Sternberg), HLA-DR/alpha and myeloid/ histiocyte antigen. A line of FITCconjugated monoclonals is introduced in the catalogue, listing antibodies to pan T-cell, pan B-cell, CD8 and CD4 cells. More $\mathrm{F}\left(\mathrm{Ab}^{\prime}\right)_{2}$ antibody fragments some offered conjugated to horseradish peroxidase - have also been added.

BRL has a photobiotin labelling system which can be used as an alternative to nick translation for the nonradioactive labelling of DNA probes (Reader Service No. 104). By exposure to a strong light source, photobiotin links biotin groups to DNA. The system includes reagents for the preparation of DNA probes, control DNA to monitor performance, protocols for carrying out the procedure, and procedures for probe hybridization. BRL says one kit can label up to $50 \mu \mathrm{g}$ of DNA.

MSD Isotopes offers a wide variety of stable isotope labels for biochemistry, chemistry and other disciplines. The MSD Isotopes catalogue lists deuterium, carbon-13, nitrogen-15, oxygen isotopes and labelled compounds (Reader Service No. 105). Stable isotopes may be used to define metabolic pathways, to follow organic reactions or in GC-MS for isotope internal standards. Specific products listed in the free catalogue include pollutants, drugs, biochemicals, spin labels, algal products and NMR solvents. Amersham products (Reader Service No. 102). The kit allows researchers to prepare biotinylated primary antibodies and reduce the number of steps in immunocytochemical procedures while retaining the advantages of the biotin-streptavidin labelling system. The kit may also be used to biotinylate second antibodies where they are unavailable commercially, or to label enzymes and receptor ligands. Biotinylation reagent, buffer and purification columns for five reactions are included in the kit, along with a full protocol. Amersham says the spacer arm biotinylation reagent reduces steric hindrance between the biotin molecule and the macromolecule to which it is bound, yielding higher sensitivity.

The free 1988 catalogue from Dako Corporation, a division of Dakopatts, describes over 600 monoclonal and polyclonal antibodies, immunoenzymatic staining kits and related products (Reader Service No. 103). New products in the
Zymed is offering protein $\mathbf{G}$ isolated from Streptococcus and recombinant protein $\mathbf{G}$ produced in a strain of Escherichia coli for use in ELISAs, antibody purification and other applications (Reader Service No. 106). Zymed also sells conjugates of recombinant protein $\mathrm{G}$ to biotin, FITC, Texas Red, alkaline phosphatase, horseradish peroxidase and Sepharose 4B. Zymed says its protein $\mathrm{G}$ reagents bind to all four subclasses of human IgG and to IgG from mouse, rabbit, guinea pig, rat, goat, sheep, cow and horse, and do not bind to human $\operatorname{IgA}$ or IgM. Its recombinant protein $G$ will not bind human serum albumin, says the company.

These notes are compiled by Carol Ezzell from information provided by the manufacturers. To obtain further details about these products, use the reader service card bound inside the journal. Prices quoted are sometimes nominal, and apply only within the country indicated. 